\title{
Abbreviations
}

Abbreviation

\begin{tabular}{|c|c|}
\hline ADSR & $\begin{array}{l}\text { Alliance of Democrats of the } \\
\text { Slovak Republic }\end{array}$ \\
\hline BIS & $\begin{array}{l}\text { Security and Information } \\
\text { Service }\end{array}$ \\
\hline ČSSD & $\begin{array}{l}\text { Czech Social Democratic } \\
\text { Party }\end{array}$ \\
\hline DS & Democratic Party \\
\hline DU & Democratic Union \\
\hline EAJ & $\begin{array}{l}\text { European Association } \\
\text { of Judges }\end{array}$ \\
\hline ESWS & Coexistence \\
\hline EU & European Union \\
\hline FIDESZ & $\begin{array}{l}\text { Hungary's Youth } \\
\text { Democrats }\end{array}$ \\
\hline $\mathrm{G}_{3} \mathrm{~S}$ & $\begin{array}{l}\text { Federation of Young } \\
\text { Democrats }\end{array}$ \\
\hline HSD-SMS & $\begin{array}{l}\text { Movement for Self- } \\
\text { Administered Democracy- } \\
\text { Society for Moravia and } \\
\text { Silesia }\end{array}$ \\
\hline HSL'S & $\begin{array}{l}\text { Hlinka's Slovak People's } \\
\text { Party }\end{array}$ \\
\hline HZDS & $\begin{array}{l}\text { Movement for a Democratic } \\
\text { Slovakia }\end{array}$ \\
\hline
\end{tabular}

Name in Source Language

Aliancia demokratov Slovenskej republiky

Bezpečnostní informační služba

Ceská strana sociálne demokratická

Demokratická strana

Demokratická únia

Együttélés-SpolužitieWspólnota-Soužití

Fiatal Demokraták Szövetsége

Grémium tretieho sektora

Hnutí za samosprávnou demokracii-Společnost pro Moravu a Slezsko

Hlinkova slovenská l'udová strana Hnutie za demokratické Slovensko 


\begin{tabular}{|c|c|c|}
\hline IMF & $\begin{array}{l}\text { International Monetary } \\
\text { Fund }\end{array}$ & \\
\hline $\mathrm{KDH}$ & $\begin{array}{l}\text { Christian Democratic } \\
\text { Movement }\end{array}$ & $\begin{array}{l}\text { Krest'anskodemokraticke } \\
\text { hnutie }\end{array}$ \\
\hline KDU-ČSL & $\begin{array}{l}\text { Christian Democratic } \\
\text { Union-Czech People's Party }\end{array}$ & $\begin{array}{l}\text { Křest’anská a } \\
\text { demokratická } \\
\text { unie-Československá } \\
\text { strana lidová }\end{array}$ \\
\hline KSČM & Communist Party & $\begin{array}{l}\text { Komunistická strana Čech } \\
\text { a Moravy }\end{array}$ \\
\hline LSU & Liberal Social Union & Liberálně sociální unie \\
\hline MK & Hungarian Coalition & Magyar Koalíció \\
\hline MKDM & $\begin{array}{l}\text { Hungarian Christian } \\
\text { Democratic Movement }\end{array}$ & $\begin{array}{l}\text { Magyar } \\
\text { Kereszténydemokrata } \\
\text { Mozgalom }\end{array}$ \\
\hline MKP & $\begin{array}{l}\text { Party of the Hungarian } \\
\text { Coalition }\end{array}$ & Magyar Koalíció Pártja \\
\hline NATO & $\begin{array}{l}\text { North Atlantic Treaty } \\
\text { Organization }\end{array}$ & \\
\hline OAS & $\begin{array}{l}\text { Organization of American } \\
\text { States }\end{array}$ & \\
\hline ODA & Civic Democratic Alliance & $\begin{array}{l}\text { Občanská demokratická } \\
\text { aliance }\end{array}$ \\
\hline ODS & Civic Democratic Party & $\begin{array}{l}\text { Občanská demokratická } \\
\text { strana }\end{array}$ \\
\hline $\mathrm{OF}$ & Civic Forum & Občanské fórum \\
\hline OSCE & $\begin{array}{l}\text { Organization for Security } \\
\text { and Co-operation in Europe }\end{array}$ & \\
\hline SDK & Slovak Democratic Coalition & $\begin{array}{l}\text { Slovenská demokratická } \\
\text { koalícia }\end{array}$ \\
\hline $\mathrm{SDL}^{\prime}$ & Party of the Democratic Left & $\begin{array}{l}\text { Strana demokratickej } \\
\text { l'avice }\end{array}$ \\
\hline SIS & Slovak Information Service & $\begin{array}{l}\text { Slovenská informačná } \\
\text { služba }\end{array}$ \\
\hline SNS & Slovak National Party & Slovenská národná strana \\
\hline SOP & $\begin{array}{l}\text { Party of Civic } \\
\text { Understanding }\end{array}$ & $\begin{array}{l}\text { Strana občianskeho } \\
\text { porozumenia }\end{array}$ \\
\hline SPR-RSČ & $\begin{array}{l}\text { Assembly for the Republic- } \\
\text { Republican Party of } \\
\text { Czechoslovakia }\end{array}$ & $\begin{array}{l}\text { Sdružení pro } \\
\text { republiku-Republikánská } \\
\text { strana Československa }\end{array}$ \\
\hline
\end{tabular}


Abbreviations xix

$\begin{array}{lll}\text { STV } & \text { Slovak Television } & \text { Slovenská televízia } \\ \text { SV } & \text { Common Choice } & \text { Spoločná vol'ba } \\ \text { UN } & \text { United Nations } & \\ \text { US } & \text { Freedom Union } & \text { Unie svobody } \\ \text { VPN } & \text { Public Against Violence } & \text { Verejnost' proti násiliu } \\ \text { ZRS } & \text { Association of Workers of } & \text { Združenie robotníkov } \\ & \text { Slovakia } & \text { Slovenska } \\ \text { ZS } & \text { Green Party } & \text { Strana zelených }\end{array}$





\section{ELECTED AFFINITIES}


